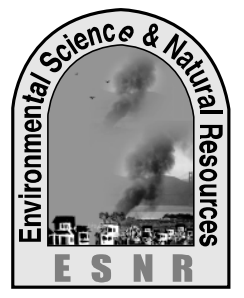

J. Environ. Sci. \& Natural Resources, 7(1): 117 - 120, 2014

ISSN 1999-7361

\title{
Processing and Preservation of Ginger Juice
}

\author{
S. Ahammed ${ }^{1}$, M. M. H. Talukdar ${ }^{1}$, M. S. Kamal ${ }^{2}$ \\ ${ }^{1}$ Department of Food Engineering and Technology \\ Hajee Mohammad Danesh Science and Technology University, Dinajpur-5200 \\ ${ }^{2}$ Department of Food Technology and Rural Industries \\ Bangladesh Agricultural University, Mymensingh-2202
}

\begin{abstract}
The fresh ginger and ginger juice were analyzed for proximate composition, microbiological status, sensory attributes and overall storage stability. Fresh gingers were processed in sugar and other preservatives. The proximate composition of fresh ginger was moisture content $87.4 \%$, protein content $1.6 \%$, fat content $0.8 \%$, ash content $1.0 \%$, and vitamin-C $4 \mathrm{mg} / 100 \mathrm{gm}$. Vitamin-C content decreased in all the samples. This vitamin was lost by oxidation and heat following first-order kinetics which stated that concentration has exponential relationship with time. The microbiological studies revealed that total viable counts (bacteria, yeast and mould) were a small in juice. The acceptability of processed juice was evaluated by the panelists using 1-9 hedonic scale. The panelists tasted the products and assigned marks for color, flavor, pungency and overall acceptability. The mean score for color, flavor, pungency and overall acceptability showed secured score within the acceptable limit ranging from 6.30 to 8.0, ranking' like slightly' to' like very much'. Storage studies were carried out up to four months at room temperature $\left(25^{\circ} \mathrm{C}\right)$. The interval was 15 days up to first two months and one month interval for the next two months.
\end{abstract}

Key Words: Ginger Juice, Processing, Preservation

\section{Introduction}

Ginger (Zingiber officinale) the underground rhizome of the zingiberous herbaceous plant, is originated in the Southeast Asia. In Bangladesh, it is known as 'Ada'. It is one of the earliest oriental spices known to Europe and is still highly demand in today.

The aroma of ginger is pleasant and spicy and its flavor penetrating and biting due to presence of antiseptic or pungent compounds, which make it indispensable in the manufacture of a number of food products like ginger bread, confectionery, ginger ale, curry powders, certain curried meats, table sauces, in pickling and in the manufacture of certain soft drinks like cordials, ginger cocktail, carbonated drinks, bitters etc. Ginger is also used for the manufacture of ginger oil, oleoresin, essences, tinctures etc (Pruthi, 1998).

The ginger juice, as a convenience food ingredient, may find its widespread use in the industry. The catering industry is itself made up of a variety of outlets such as hotels, restaurants, canteens, hospitals, nursing homes, school meals and prisons. Higher incomes and more active life styles in recent years have resulted in consumers seeking high quality, convenient food items in the markets. The ginger juice, for its anticipated widespread use, may help fill the needs of consumers for a convenient food ingredient.

\section{Materials and Methods}

The ginger (Zingiberofficinale) collected from the local market was used in the thesis experiment.
Preservatives such as potassium metabisulphite (KMS, $\left.\mathrm{K}_{2} \mathrm{~S}_{2} \mathrm{O}_{5}\right)$, sodium benzoate $\left(\mathrm{C}_{6} \mathrm{H}_{5}-\mathrm{COONa}\right)$, citric acid, and other chemicals were used from the laboratory stock. Polyethylene terephthalate (PET) and plastic bottles were used as packaging materials. The capacity of each bottle was $100 \mathrm{ml}$. Brief descriptions of the methods followed for the study is given below:

Preparation of Juice: Fresh raw ginger was selected and washed with water properly. Then extracted the juice by using blender and then filtered with cloth by pressing hand. After juice extraction these were measured in a ratio of (1.22:1) water: sugar and made syrup of sugar, water and citric acid. Then boiled the juice at $80-90{ }^{\circ} \mathrm{C}$ and after that added the KMS and bottled. Various ingredients of three samples which were as follows: Chemical Analysis: The processed samples were analyzed for their moisture, ash, acidity, vitamin $\mathrm{C}, \mathrm{pH}$, fat, protein and vitamin - $\mathrm{C}$ (AOAC, 2001)

Microbiological examination: For total viable count of microorganism present in juice, standard plate count method was followed according to the method described in "Recommended method for the microbiological examination of food "American Public Health Association (Leverington, 1969).

Sensory evaluation: The consumer's acceptability of processed juice was evaluated by the selection of panelist. The hedonic rating test was used to determine this acceptability described by Ranganna (1992). The panelists were selected from the teachers, students and lab attendant of the faculty of AgroIndustrial and Food Process Engineering, Hajee Mohammod Danesh Science and Technology 
University, Dinajpur. The products were served to each judge who independently examined the following characteristics (a) Colour (b) Flavor (c) Pungency (d) Overall acceptability.

The scale was arranged such that: 9= Like extremely, $8=$ like very much, $7=$ like moderately, $6=$ like slightly, $5=$ neither like nor dislike, $4=$ dislike slightly, $3=$ dislike moderately, $2=$ dislike very much and $1=$ dislike extremely.

Storage studies: Three different samples of ginger juice were used for storage studies at room temperature $\left(25^{\circ} \mathrm{C}-27^{\circ} \mathrm{C}\right)$ from $0-4$ months. The effect of storage time (30, 60, 90 and 120 days) on physical properties such as color, flavor and pungency of the juices were studied. All the samples of ginger juice were in good condition up to 4 months of storage.

\section{Results and Discussion}

Three different samples of ginger juice were used for storage studies at room temperature $\left(25^{\circ} \mathrm{C}-27^{\circ} \mathrm{C}\right)$ from 0-4 months. The effect of storage time $(30,60,90$ and 120 days) on physical properties such as color, flavor and pungency of the juices were studied. All the samples of ginger juice were in good condition up to 4 months of storage.

The average analysis of ginger juice were analyzed for moisture $94.97 \%$, protein $1.08 \%$, fat $1.17 \%$, ash $0.71 \%$, vitamin $\mathrm{C}$ (ascorbic acid) $15.67 \%$, acidity $0.13 \%$ respectively.

Storage studies of Ginger Juice: Three different samples of ginger juice were used for storage studies at room temperature $25^{\circ}-30^{\circ} \mathrm{C}$ and $0-120$ days. The effect of storage time (30, 60, 90 and 120 days) on physical properties such as color, flavor and pungency of the juices were studied. All the samples of ginger juice were in good condition up to 4 months of storage. Storage studies were carried out for four months at room temperature $\left(25^{\circ} \mathrm{C}\right)$ and samples were taken at an interval of 30 days. The samples were then observed for some parameters such as color, flavor, pungency and visual fungal growth etc. It also revealed that all the samples were found to be shelf stable up to six months. This study indicates a good prospect of processing of ginger by juice. Further investigation is necessary to study the shelf life, economic and safety aspects of the products before commercial exploration.

Sensory evaluation of Ginger Juice: A two-way analysis of variance (ANOVA) was carried out for color preference and result revealed that there was slightly significant $(\mathrm{p}<0.01)$ indifference in color acceptability among all the samples. In case of flavor preference among the samples a two-way analysis of variance (ANOVA) showed that there was no significant $\quad(p<0.01)$ indifference in flavor acceptability among the ginger juice. From the calculation and table the result revealed that the flavors of different samples were equally accepted. It is apparent from the result of the ANOVA that there were significant $(\mathrm{p}<0.01)$ difference in overall acceptability of the sample tasted. It is shown that the sample -2 is the highly acceptable securing out of three samples. However, all the samples were acceptable to the panelists.

Microbiological study of shelf stable ginger juice:

The total number of viable bacteria in different samples at different storage period has been shown Table 5. Sample-1 showed maximum count and sample-2 showed minimum count. After 60 days storage of ginger juice by bottling with preservatives very little difference is observed in microbiological load compared to that of 90 days storage for both

\section{References}

AOAC, 2001. Official Methods of Analysis of the Association of Official Analytical Chemist. 18th Ed. Washington D.C.

Leverington, R.E. 1969. Ginger Processing investigation 3: improving the quality of processed ginger, Queensland J. Agric. Amin, Sci, 26, 264-270.

Pruthi, J.S. 1998. Spices and condiments. National Book Trust $5^{\text {th }}$ Ed. India. P.152. 
Table-1: Various ingredients of Ginger Juice

\begin{tabular}{|l|c|c|c|}
\hline Ingredients & Sample-1 & Sample -2 & Sample -3 \\
\hline Juice $(\mathrm{ml})$ & 85 & 75 & 75 \\
\hline Water $(\mathrm{ml})$ & 150 & 160 & 170 \\
\hline Sugar $(\mathrm{gm})$ & 35 & 25 & 15 \\
\hline Citric acid (ml) & 1.50 & 1.50 & 50 \\
\hline KMS (gm) & 30 & 40 & .50 \\
\hline
\end{tabular}

Table-2: Chemical Composition of Processed Juice

\begin{tabular}{|c|c|c|c|c|c|c|c|}
\hline No. of Sample & Moisture (\%) & Fat (\%) & Protein (\%) & $\begin{array}{c}\text { Ash } \\
(\%)\end{array}$ & Acidity (\%) & Vit-C (mg/100gm) & $\mathrm{pH}$ \\
\hline S-1 & 95 & 1.12 & 1.02 & 0.65 & 0.10 & 15 & 4.5 \\
\hline S-2 & 95.9 & 1.23 & 0.99 & 0.88 & 0.18 & 18 & 4.8 \\
\hline S-3 & 94 & 1.16 & 1.22 & 0.61 & 0.12 & 14 & 4.4 \\
\hline
\end{tabular}

Table-3: Storage studies of Ginger Juice

\begin{tabular}{|l|l|l|l|l|l|}
\hline $\begin{array}{c}\text { Storage } \\
\text { period } \\
\text { (days) }\end{array}$ & Sample code & \multicolumn{1}{|c|}{ Color } & Flavor & Pungency & Visual fungal growth \\
\hline \multirow{3}{*}{30} & Sample-1 & Good & Good & High & Not Visual \\
\cline { 2 - 6 } & Sample-2 & Good & Good & Moderate & Not visual \\
\cline { 2 - 6 } & Sample-3 & Good & Good & High & Not visual \\
\hline \multirow{3}{*}{60} & Sample-1 & Good & Good & Moderate & Not visual \\
\cline { 2 - 6 } & Sample-2 & Good & Good & Moderate & Not visual \\
\cline { 2 - 6 } & Sample-3 & Slide dark & Good & Moderate & Slide visual \\
\hline \multirow{4}{*}{90} & Sample-1 & Good & $\begin{array}{l}\text { Slide } \\
\text { change }\end{array}$ & Slide change & Not visual \\
\cline { 2 - 6 } & Sample-2 & Good & Good & Moderate & Not visual \\
\cline { 2 - 6 } & Sample-3 & Brown dark & $\begin{array}{l}\text { Slide } \\
\text { change }\end{array}$ & Slide change & Mould growth \\
\hline \multirow{3}{*}{120} & Sample-1 & Slide dark & Low & Change & Mould \\
\cline { 2 - 6 } & Sample-2 & Good & Good & Moderate & Not visual \\
\cline { 2 - 3 } & Concentrate dark & Low & Spoil & Spoil \\
\hline
\end{tabular}

Table-4. Mean score for color, flavor, texture and overall acceptability of various Ginger Juice

\begin{tabular}{|l|c|c|c|c|}
\hline \multirow{3}{*}{ Sample code } & \multicolumn{4}{|c|}{ Sensory attributes } \\
\cline { 2 - 5 } & Color & Flavor & Pungency & Overall Acceptability \\
\hline S-1 & 6.2 & 6.8 & 6.1 & 5.9 \\
\hline S-2 & 7.0 & 6.7 & 5.1 & 6.2 \\
\hline S-3 & 6.4 & 6.7 & 5.9 & 6.1 \\
\hline
\end{tabular}


Table-5. Growth of total viable load at different storage period

\begin{tabular}{|c|c|c|c|c|c|c|c|}
\hline \multirow{2}{*}{ 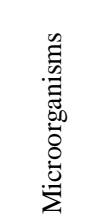 } & \multirow[b]{2}{*}{$\begin{array}{l}\text { Types of } \\
\text { Sample }\end{array}$} & \multicolumn{2}{|c|}{ Count on 30 days } & \multicolumn{2}{|c|}{ Count on 60 days } & \multicolumn{2}{|c|}{ Count on 90 days } \\
\hline & & $\begin{array}{c}\text { count on } 30 \text { days } \\
\text { cfu/gm }\end{array}$ & $\begin{array}{c}\log \\
\text { (cfu/gm) }\end{array}$ & $\mathrm{cfu} / \mathrm{gm}$ & $\begin{array}{c}\log \\
\text { (cfu/gm) }\end{array}$ & $\mathrm{cfu} / \mathrm{gm}$ & $\begin{array}{c}\log \\
\text { (cfu/gm) }\end{array}$ \\
\hline \multirow{3}{*}{ Bacteria } & Sample-1 & $10 \times 10^{2}$ & 5.48 & $35 \times 10^{6}$ & 7.54 & $25 \times 10^{6}$ & 7.4 \\
\hline & Sample-2 & $10 \times 10^{3}$ & 5.48 & $10 \times 10^{5}$ & 6.0 & $15 \times 10^{5}$ & 5.9 \\
\hline & Sample-3 & $10 \times 10^{3}$ & 5.48 & $8 \times 10^{5}$ & 3.9 & $20 \times 10^{5}$ & 5.6 \\
\hline \multirow{3}{*}{ Mould } & Sample-1 & $10 \times 10^{2}$ & 3.79 & $23 \times 10^{6}$ & 3.4 & $15 \times 10^{6}$ & 7.7 \\
\hline & Sample-2 & $15 \times 10^{2}$ & 3.79 & $30 \times 10^{5}$ & 5.6 & $56 \times 10^{5}$ & 5.3 \\
\hline & Sample-3 & $8 \times 10^{3}$ & 3.79 & $14 \times 10^{5}$ & 3.5 & $36 \times 10^{5}$ & 5.9 \\
\hline \multirow{3}{*}{ Yeast } & Sample-1 & $30 \times 10^{4}$ & 6.48 & $18 \times 10^{6}$ & 7.54 & $27 \times 10^{6}$ & 7.4 \\
\hline & Sample-2 & $20 \times 10^{4}$ & 4.48 & $17 \times 10^{5}$ & 6 & $28 \times 10^{5}$ & 7.9 \\
\hline & Sample-3 & $15 \times 10^{4}$ & 5.48 & $28 \times 10^{5}$ & 3.9 & $25 \times 10^{5}$ & 8.6 \\
\hline \multirow{2}{*}{ 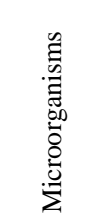 } & \multirow[b]{2}{*}{$\begin{array}{l}\text { Types of } \\
\text { Sample }\end{array}$} & \multicolumn{2}{|c|}{ Count on 30 days } & \multicolumn{2}{|c|}{ Count on 60 days } & \multicolumn{2}{|c|}{ Count on 90 days } \\
\hline & & $\begin{array}{c}\text { count on } 30 \text { days } \\
\mathrm{cfu} / \mathrm{gm}\end{array}$ & $\begin{array}{c}\log \\
\text { (cfu/gm) }\end{array}$ & $\mathrm{cfu} / \mathrm{gm}$ & $\begin{array}{c}\log \\
\text { (cfu/gm) }\end{array}$ & $\mathrm{cfu} / \mathrm{gm}$ & $\begin{array}{c}\log \\
\text { (cfu/gm) }\end{array}$ \\
\hline \multirow{3}{*}{ Bacteria } & Sample-1 & $10 \times 10^{2}$ & 5.48 & $35 \times 10^{6}$ & 7.54 & $25 \times 10^{6}$ & 7.4 \\
\hline & Sample-2 & $10 \times 10^{3}$ & 5.48 & $10 \times 10^{5}$ & 6.0 & $15 \times 10^{5}$ & 5.9 \\
\hline & Sample-3 & $10 \times 10^{3}$ & 5.48 & $8 \times 10^{5}$ & 3.9 & $20 \times 10^{5}$ & 5.6 \\
\hline \multirow{3}{*}{ Mould } & Sample-1 & $10 \times 10^{2}$ & 3.79 & $23 \times 10^{6}$ & 3.4 & $15 \times 10^{6}$ & 7.7 \\
\hline & Sample-2 & $15 \times 10^{2}$ & 3.79 & $30 \times 10^{5}$ & 5.6 & $56 \times 10^{5}$ & 5.3 \\
\hline & Sample-3 & $8 \times 10^{3}$ & 3.79 & $14 \times 10^{5}$ & 3.5 & $36 \times 10^{5}$ & 5.9 \\
\hline \multirow{3}{*}{ Yeast } & Sample-1 & $30 \times 10^{4}$ & 6.48 & $18 \times 10^{6}$ & 7.54 & $27 \times 10^{6}$ & 7.4 \\
\hline & Sample-2 & $20 \times 10^{4}$ & 4.48 & $17 \times 10^{5}$ & 6 & $28 \times 10^{5}$ & 7.9 \\
\hline & Sample-3 & $15 \times 10^{4}$ & 5.48 & $28 \times 10^{5}$ & 3.9 & $25 \times 10^{5}$ & 8.6 \\
\hline
\end{tabular}

